American Journal of Environmental Sciences 4 (6): 589-594, 2008

ISSN 1553-345X

(C) 2008 Science Publications

\title{
Prospects of Wind Farm Development in Algeria
}

\author{
${ }^{1}$ Y. Himri, ${ }^{2}$ A. Boudghene Stambouli and ${ }^{3}$ B. Draoui \\ ${ }^{1}$ Electricity and Gas National Enterprise (Sonelgaz), Béchar, Algeria \\ ${ }^{2}$ Department of Electronics, University of Sciences and Technology of Oran, Algeria \\ ${ }^{3}$ Department of Mechanical Engineering, University of Béchar, Algeria
}

\begin{abstract}
This study utilized wind speed data over a period of almost 10 years between 1977 and 1988 from three stations, namely Adrar, Timimoun and Tindouf in order to assess the energy output for a $30 \mathrm{MW}$ installed capacity wind farm at each site in Algeria, in terms of gross energy, renewable energy delivered, specific yield and wind farm capacity factor. The energy output analysis is done using three WECSs of rated capacity 600,1000 and $2000 \mathrm{~kW}$. The RETScreen model is used to perform the economical feasibility study of the wind farms at these locations. The study concludes that the wind farm consisting of 30 wind turbines of $1 \mathrm{MW}$ rated power each is more feasible for all sites than using other WECSs. Finally wind park development at Adrar will avoid 45111 tons of greenhouse gases each year and about 1127775 of tons of GHG over the life time of the wind power plant. Similarly, at Timimoun and Tindouf a total of 900925 and 639475 tons of GHG could be avoided from entering into the local atmosphere of these stations.
\end{abstract}

Key words: Wind farm, RETScreen model, Algeria

\section{INTRODUCTION}

An accurate wind resource assessment is an important and critical factor to be well understood for harnessing the power of the wind. It is well known that an error of $1 \%$ in wind speed measurements leads to almost $2 \%$ error in energy output. As we know that wind resources are seldom consistent and vary with time of the day, season of the year, height above the ground, topography and from year to year, hence should be investigated carefully and completely. According to Tennis et al. ${ }^{[1]}$ the wind resource assessment powering a wind farm project is as fundamental to the project's success as rainfall is to alfalfa production. So, one who is interested in a wind farm development should know that how strong are the winds at the site of interest and how much energy will the wind farm produce in these winds. Potts et al. ${ }^{[2]}$ performed the wind resources assessment of Western and Central Massachusetts using Wind Map software which is based on Geographic Information Systems (GIS). The authors utilized wind speed data from five locations and upper air data from one location as input to Wind Map software to produce estimates of wind speed at 50 meter. Brower ${ }^{[3]}$ used GIS based tools to develop wind resource map for New Mexico using wind speed data from 67 stations and elevation data in the region. Rehman ${ }^{[4]}$ presented the energy output and economical analysis of $30 \mathrm{MW}$ installed capacity wind farms at five coastal locations in terms of unadjusted energy, gross energy, renewable energy delivered specific yield and plant capacity factor using wind machines of 600,1000 and $1500 \mathrm{~kW}$. In another study, Rehman ${ }^{[5]}$ performed a detailed analysis of wind speed in terms of energy yield, effect of hubheight on energy yield, plant capacity factor, etc. for an industrial city situated on the northwest coast of Saudi Arabia. Rehman and Aftab ${ }^{[6]}$ performed detailed wind data analysis for wind power potential assessment for five coastal locations in Saudi Arabia. Rehman et al. ${ }^{[7]}$ computed the cost of energy generation at 20 locations in Saudi Arabia using net present value approach. Rehman and Halawani ${ }^{[8]}$ presented the statistical characteristics of wind speed and its diurnal variation. The autocorrelation coefficients were found to match the actual diurnal variation of the hourly mean wind speed for most of the locations used in the study. Rehman et al. ${ }^{[9]}$ calculated the Weibull parameters for 10 anemometer locations in Saudi Arabia and found that the wind speed was well represented by the Weibull distribution function. With growing global awareness of the usage of clean sources of energy, wind energy in particular, a lot of work is being carried out in different parts of the world, as can be seen from ${ }^{[10-23]}$.

In Algerian context, a company of electricity, SONELGAZ, has used photovoltaic based solar energy to power the isolated villages and remote houses of

Corresponding Author: Y. Himri, Electricity and Gas National Enterprise (Sonelgaz), Béchar, Algeria 05 rue Mokadem Ahmed, Béchar (08000) Algeria Tel: +213-74 757714 Fax: +213-49-80 3174 
south Algeria. These locations include Adrar, Timimoun (Tala Hamou-Moussa) and Tindouf (Gara Djebilet, Hassi Mounir, Draa el Khadra) as reported by Himri $^{[24]}$. At present, the SONELGAZ Company is leading the way towards the development and utilization renewable sources of energy in the country in general and wind energy in particular as can be seen from Haddouche et $a l^{[25]}$ and SONELGAZ ${ }^{[26]}$. According to Elimax ${ }^{[27]}$, Algeria is among 15 African countries (South Africa, Eritrea, Mauritania, cap avert, Algeria, Lesotho, Seychelles, Madagascar, Somalia, Djibouti, morocco, Chad, Egypt, Maurice, Tunisia) which have the good potential of wind energy.

This study utilizes the long term wind speed data for three sites, namely Adrar, Timimoun and Tindouf to investigate the economical feasibility of developing wind farms of installed capacity of $30 \mathrm{MW}$ at these sites. The energy calculations and economic analysis were performed using the RetScreen Software.

\section{WIND DATA AND SITE DESCRIPTION}

The wind speed data were collected over a period of 8 to 10 years at three sites used in this study. The details of the sites are shown in Table 1.

Table 1: Geographical coordinates of the data collection stations used in the study

\begin{tabular}{|c|c|c|c|}
\hline Location & Latitude (deg.) & Longitude (deg.) & Altitude $(\mathrm{m})$ \\
\hline Adrar & $27^{\circ} \mathrm{C} 49^{\prime} \mathrm{N}$ & $00^{\circ} \mathrm{C} 17^{\prime} \mathrm{E}$ & 263 \\
\hline Timimoun & $29^{\circ} \mathrm{C} 15^{\prime} \mathrm{N}$ & $00^{\circ} \mathrm{C} 17^{\prime} \mathrm{E}$ & 312 \\
\hline Tindouf & $27^{\circ} \mathrm{C} 40^{\prime} \mathrm{N}$ & 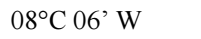 & 401 \\
\hline
\end{tabular}

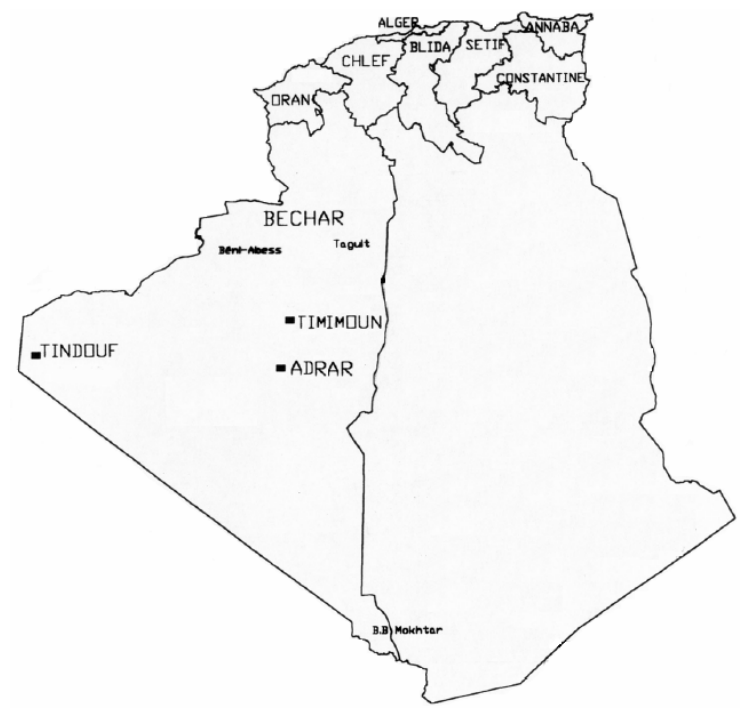

Fig. 1: Map showing the locations of the wind measurement stations
The meteorological measurements were made $10 \mathrm{~m}$ above ground level and registered every $3 \mathrm{~h}$ interval (viz. 0, 3, 6, 9, 12, 15, 18 and $21 \mathrm{~h}$ ) at all the stations. The wind data measurement stations lie in the south west region of Algeria. The geographical locations of these stations are also shown in Fig. 1.

\section{MATERIALS AND METHODS}

The energy yield from a hypothetical wind farm of 30 MW installed capacity is calculated by RetScreen software using the annual average wind speed at hub height and the energy production curve of the wind turbine.

The estimation of wind energy is obtained by taking into consideration the effect of various losses like array, airfoil soiling, icing losses, down time losses and miscellaneous losses are shown in Table 2.

The pressure and temperature adjustment coefficients which effect the energy yield were also considered, are summarized in Table 2. A value of 0.16 for wind shear exponent was used in this study.

The gross energy production and wind energy delivered using wind turbines of rated power of 600 , 1000 and $2000 \mathrm{~kW}$ are shown in Fig. 2.

It is observed that the maximum gross energy yield, without losses from Adrar, Timimoun and Tindouf was found to $109.371,87.370$ and 62.015 $\mathrm{MWh}$ respectively, is produced using the $1000 \mathrm{~kW}$ wind turbine. Wind energy delivered also follows the same trends.

Table 2: Wind energy related coefficients used in energy yield estimation

\begin{tabular}{ll}
\hline Value & Item \\
\hline 3 & Array losses, (\%) \\
2 & Airfoil soiling and /or icing losses, (\%) \\
2 & Downtime losses, (\%) \\
2 & Miscellaneous losses, (\%) \\
0.97 & Pressure adjustment coefficient \\
0.97 & Temperature adjustment coefficient \\
0.16 & Wind shear exponent \\
\hline
\end{tabular}

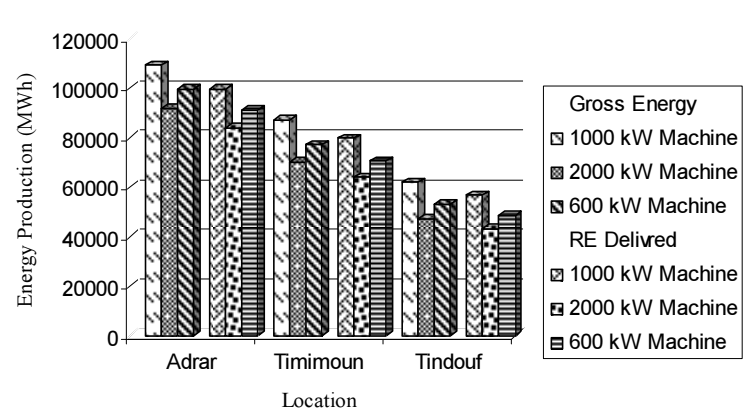

Fig. 2: Energy production using different WECS 
The highest values of the specific yield are obtained at Adrar for all the WECSs as shown in Fig. 3. The plant capacity factors obtained for all WECs at all the sites are shown in Fig. 4.

Higher capacity factor of 38 is obtained at Adrar while they fall between 30-22 at two other locations for a WECS of $1000 \mathrm{~kW}$.

The RETScreen model also calculated the reduction of GHG as a result of using wind as a source of energy to generate electricity. The resulting values of GHG per year at all locations are resumed in Fig. 5.

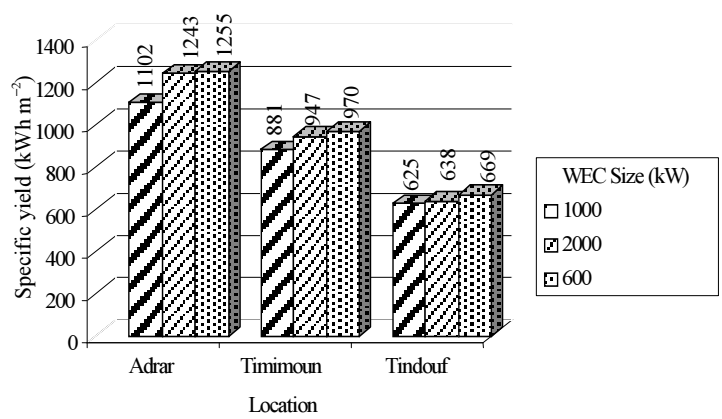

Fig. 3: Comparison of specific energy yield from different WECS

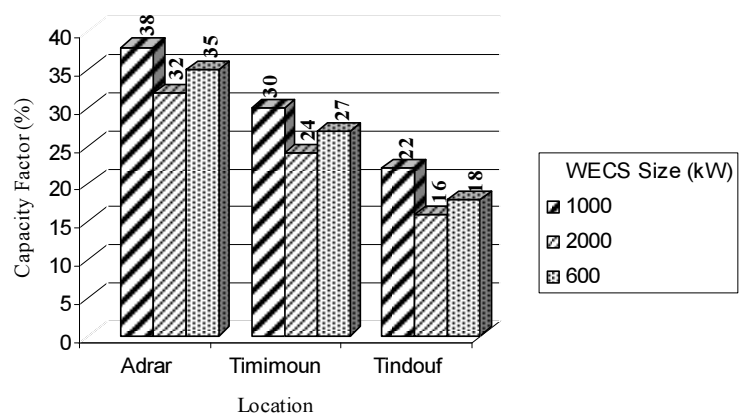

Fig. 4: Comparison of plant capacity factor computed for each location

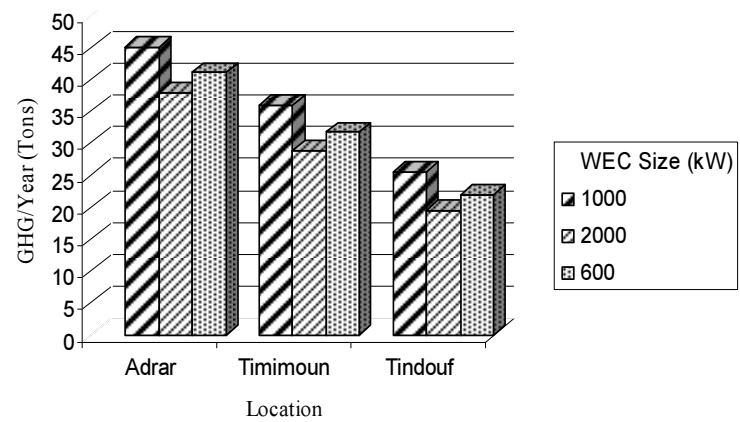

Fig. 5: Comparison of reduction in greenhouse gases per year
Using 30 WECSs of $1000 \mathrm{~kW}$ rated power at these sites (Adrar, Timimoun and Tindouf) will result in a reduction in greenhouse gases of 45111,36037 and 25 579 tons each year respectively from entering into the local atmosphere thus creating a clean and healthy atmosphere for local inhabitants.

\section{WIND ENERGY ECONOMICAL ANALYSIS}

The Retscreen model is capable of performing a detailed economical analysis of the wind energy yield using some cost and interest parameters such as discount and inflation rates, GHG emission reduction credit, project life, energy cost escalation rate, etc. The inflation and discount rates of 2.5 and $12 \%$, used in the present study, along with other cost parameters are resumed in Table 3.

The feasibility study on renewable energy equipment including the wind machine and tower, balance of plant, development, engineering, miscellaneous and operation and maintenance costs are shown in Table 4.

In all the calculations, the same values are used for all sites. As seen in this Table, the major cost of US \$ 38010000 correspond to a WECS of $600 \mathrm{~kW}$ machines and is about $77.1 \%$ of the total project capital cost.

The economic feasibility study is performed in terms of the pre-tax Internal Rate of Return (IRR) and Return On Investment (ROI), the after tax values, simple pay back period (SPP), Net Present Value (NPV), annual life cycle saving (ALCS), Year to Positive Cash Flow (YPCF) and benefit cost ratio (B-C).

The IRR for all the locations using three different types of WECS in shown in Fig. 6

It indicates that the project of $30 \mathrm{MW}$ installed capacity for all types of WECS is feasible for all sites. For a WECS of $1000 \mathrm{~kW}$ size the pre-tax Internal Rate of Return (IRR) and Return On Investment (ROI) was found to be $62.7,45.6$ and $26.8 \%$ for Adrar, Timimoun and Tindouf sites, respectively. The after tax values were also found to be the same as pre-tax values of IRR and ROI.

\begin{tabular}{ll} 
Table 3: Summary of economic input parameters for cost analysis ${ }^{[28]}$ \\
\hline Value & Items \\
\hline 0.0950 & Avoided cost of energy, $(\$ / \mathrm{kWh})$ \\
0.025 & RE production credit, $(\$ / \mathrm{kWh})$ \\
10 & RE production credit duration, (year) \\
2.5 & RE credit escalation rate, $(\%)$ \\
5 & GHG emission reduction credit, $\left(\$ / \mathrm{t}_{\mathrm{co} 2}\right)$ \\
21 & GHG reduction credit duration, $($ year $)$ \\
0 & GHG credit escalation rate, $(\%)$ \\
5 & Energy cost escalation rate, $(\%)$ \\
2.5 & Inflation, $(\%)$ \\
12 & Discount rate, $(\%)$ \\
25 & Project life, $($ year $)$ \\
\hline
\end{tabular}


Am. J. Environ. Sci., 4 (6): 589-594, 2008

Table 4: Cost breakdown of wind farm development elements (US\$)

\begin{tabular}{|c|c|c|c|c|c|c|}
\hline \multirow{2}{*}{$\begin{array}{l}\text { WECS } \\
\text { cost items }\end{array}$} & \multicolumn{2}{|c|}{$600 \mathrm{~kW}$} & \multicolumn{2}{|c|}{$1000 \mathrm{~kW}$} & \multicolumn{2}{|c|}{$2000 \mathrm{~kW}$} \\
\hline & Cost & $(\%)$ & Cost & $(\%)$ & Cost & $(\%)$ \\
\hline Feasibility study & 195200 & 0.4 & 195200 & 0.4 & 195200 & 0.4 \\
\hline Development & 770500 & 1.6 & 770500 & 1.6 & 770500 & 1.6 \\
\hline Engineering & 610500 & 1.2 & 610500 & 1.3 & 610500 & 1.3 \\
\hline Energy equipment & 38010000 & 77.1 & 37350000 & 77.6 & 36855000 & 77.4 \\
\hline Balance of plant & 6000000 & 12.2 & 5593000 & 11.6 & 5593000 & 11.7 \\
\hline Miscellaneous & 3715275 & 7.5 & 3628305 & 7.5 & 3587972 & 7.5 \\
\hline $\mathrm{O}$ and $\mathrm{M}$ costs & 537531 & - & 537470 & - & 748442 & - \\
\hline
\end{tabular}
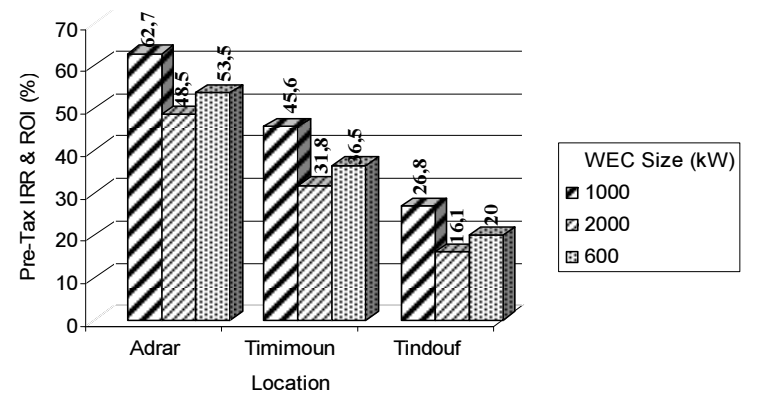

Fig. 6: Pre-tax Internal Rate of Return (IRR) and Return On Investment (ROI)

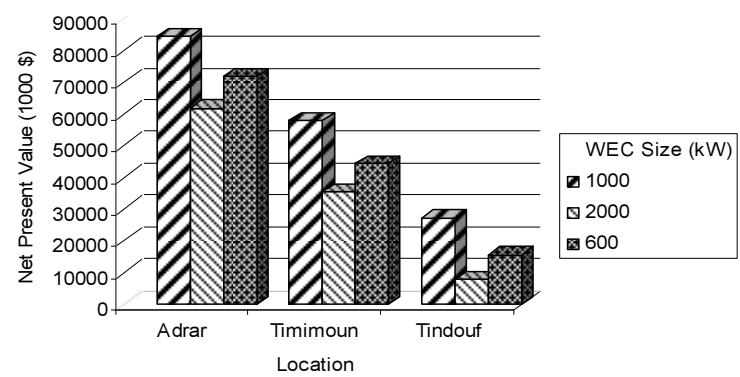

Fig. 7: Net Present Value (NPV) for discount 12\%

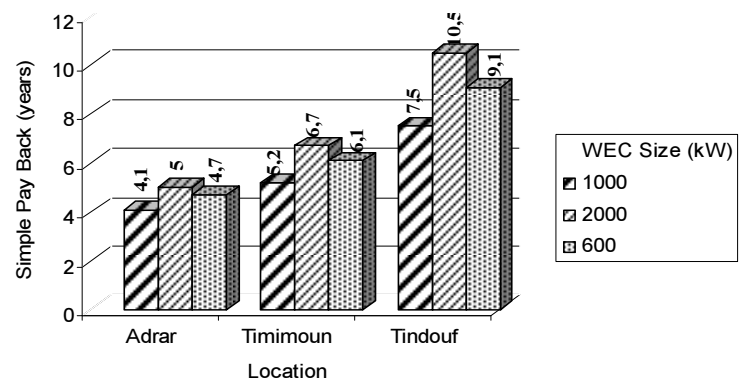

Fig. 8: Comparison of Simple Payback Period (SPP) for Wind Park project using three different wind machines

Positive values of NPV demonstrate that the project is feasible. The NPVs calculated using the discount rate at $12 \%$. As shown in Fig. 7.

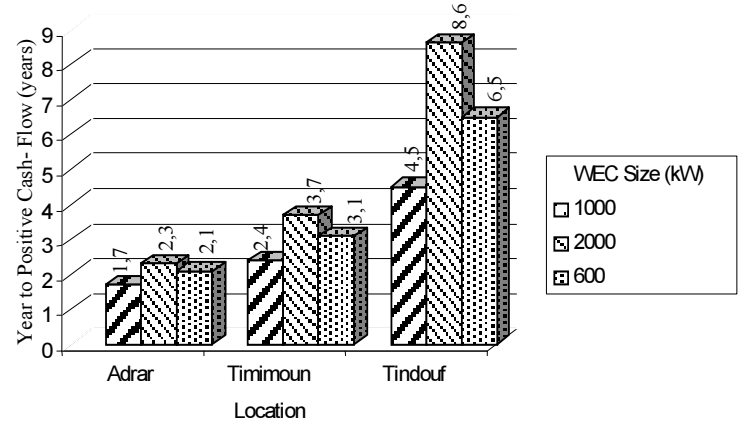

Fig. 9: Number of Years to Positive Cash Flow (YPCF) for wind farms developed using three different types of WECS

The project is feasible for all sites and for all types of WECS considered. For $1000 \mathrm{~kW}$ machines the net present value for Adrar, Timimoun and Tindouf were found to be US \$ 84229 957, 57781209 and 27300 034, respectively.

Shorter payback period means a desirable investment. Appositive case would be an indication that the annual costs incurred are higher than the annual savings generated. The SPPs calculated by the RETScreen model for all the wind parks are shown in Fig. 8.

Shorter SPPs are found for wind parks developed using $1000 \mathrm{~kW}$ wind machines. The minimum payback periods of 4.1, 4.7 and 5.0 years are found for wind park projects at Adrar corresponding to WECSs of 1000,600 and $2000 \mathrm{~kW}$ rated capacity respectively.

At other locations, these periods were found to be of the order of 5 or more years. It's the same tendency for the YPCF as shown in Fig. 9.

The ALCS were found to be positive at all the locations for all the WECSs as seen in Fig. 10.

The B-C which is the ratio of the net benefits to costs of the project. Ratios greater than 1 are indicative of profitable projects. As shown in Fig. 11. The B-C values are found to be positive for all WECSs at all sites. 
Am. J. Environ. Sci., 4 (6): 589-594, 2008

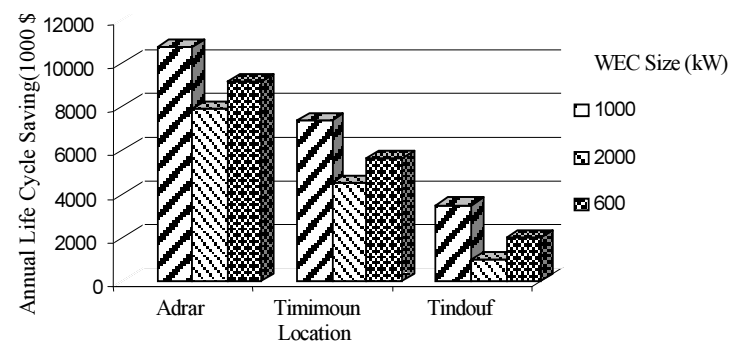

Fig. 10: Annual life cycle saving (ALCS) for discount rate of $12 \%$

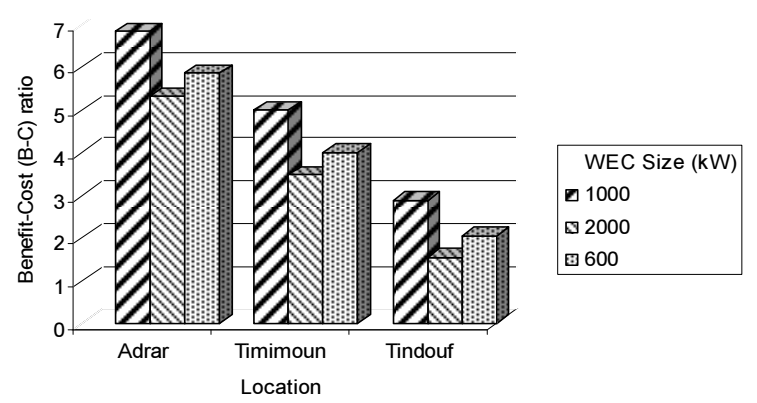

Fig. 11: Comparison of benefit cost (B-C) ratio at all locations for discount of $12 \%$

\section{CONCLUSION}

The economic analysis developed in this article shows that the wind farm consisting of 30 wind turbines of $1 \mathrm{MW}$ rated power each is more feasible for all sites compared to the other WECSs.

The study found the following salient features as the outcome of the analysis:

- Wind farms of $30 \mathrm{MW}$ installed capacity at Adrar, Timimoun and Tindouf, if developed, could produce 99851,79765 and $56617 \mathrm{MWh}$ of electricity annually taking into consideration the temperature and pressure adjustment coefficients of about $6 \%$ and all other losses of about $10 \%$, respectively

- It was noticed such a development at these sites could result into avoidance of 45111 tons of greenhouse gases from entering into the local atmosphere of Adrar each year and about 1127775 of tons of GHG over the life time of the wind power plant. Similarly, at Timimoun and Tindouf a total of 900925 and 639475tons of GHG could be avoided from entering into the local atmosphere of these stations

- The plant capacity factors at Adrar, Timimoun and Tindouf were found to be 38,30 and $22 \%$, respectively
- The economical feasibility study made based on the assumed economical parameters from the literature, showed that the positive cash flow could be obtained in 1.7, 2.4 and 4.5 years at Adrar, Timimoun and Tindouf, respectively with corresponding benefit cost ratio (B-C) of 6.83, 5.00 and 2.89

\section{ACKNOWLEDGEMENT}

The authors would like to thank Mr S. Guezzane and Mrs R. Aissaoui at CREDEG / Direction Etudes and Développement SONELGAZ for their cooperation.

\section{REFERENCE}

1. Tennis, M.W., S. Clemmer and J. Howland, 1999. Assetssing Wind Resources: A Guide for Landowners, Project Developers and Power Suppliers, Union of Concerned Scientist.

2. Potts, J.R., S.W. Pierson, P.P. Mathisen, J.R. Hamel and V.C. Babau, 2001. Wind Energy Assessment of Western and Central Massachusetts. AIAA-2001-0060.

3. Brower, M., 1997. New Maxico Wind Resources: AGIS Approach, New Maxico Energy, Minerals and Natural Resources Department, Final Report, September.

4. Rehman, S., 2004. Prospects of wind farm development in Saudi Arabia. Renew. Energ., 30: 447-463.

5. Rehman, S., 2004. Wind energy resource assessment for yanbo, Saudi Arabia. Energ. Convers. Manage., 45: 2019-2032. http://cat.inist. $\mathrm{fr} /$ ?aModele $=$ afficheN\&cpsidt $=15718324$.

6. Rehman, S. and A. Aftab, 2004. Assessment of wind energy potential for coastal locations of the kingdom Saudi Arabia. Energ. Int. J., 29: 1105-1115.

7. Rehman, S., T.O. Halawnai and M. Mohandes, 2003. Wind power cost assessment at twenty locations in the kingdom of Saudi Arabia. Renew. Energ., 28: 573-583.

8. Rehman, S. and T.O. Halawani, 1994. Statistical characteristics of wind in Saudi Arabia. Renew. Energ., 4: 49-956.

9. Rehman, S., T.O. Halawani and T. Husain, 1994. Weibull parameters for wind speed distribution in Saudi Arabia. Solar Energ., 53: 73-479. http://cat. inist.fr/?aModele $=$ afficheN\&cpsidt $=3332516$.

10. IEPF, 2000. Le programme solaire mondial: Une nouvelle dynamique pour les EnR Institut de l'énergie et de l'environnement de la francophonie, Québec. 
11. Jaramillo, O.A. and M.A. Borja, 2004. Wind speed analysis in La Ventosa, Mexico: A bimodal probability distribution case. Renew. Energ., 29: 1613-1630.

12. Kainkwa, R.M.R., 2000. Wind speed pattern and the available wind power at Basotu, Tanzania, Renew. Energ., 21: 289-295.

13. Celik, A.N., 2003. Energy output estimation for small-scale wind power generators using weibullrepresentative wind data. J. Wind Eng. Ind. Aerodynam., 91: 693-707. 10.1016/S01676105(02)00471-3

14. Ackermann, T. and L. Soder, 2000. Wind energy technology and current status: A review. Renew. Sustain. Energ. Rev., 4: 315-374. DOI: 10.1016/S1364-0321(00)00004-6.

15. Jebaraj, S., S. Iniyan, 2006. A review of energy models. Renew. Sustain. Energ. Rev., 10: 281-311. http://cat.inist.fr/?aModele $=$ afficheN\&cpsidt $=1778$ 8660

16. Perez, I.A., M.A. Garcia and M.L. Sanchez et al., 2004. Autocorrelation analysis of meteorological data from a RASS sodar. J. Applied Meteorol., 43: 213-1223. http://cat.inist.fr/ ?aModele $=$ afficheN\&cpsidt $=16043090$

17. Akpinar, K.E. and S. Akpinar, 2005. An Assessment on Seasonal Analysis of Wind Energy Characteristics and Wind Turbine Characteristics, Energ. Convers. Manage., 46: 1848-1867. http:// cat.inist.fr/?aModele $=$ afficheN\&cpsidt $=16637873$.

18. Acker, T.L., S.K. Williams, E.P.N. Duque, G. Brummels and J. Buechler, 2007. Wind resource assessment in the state of Arizona: Inventory, capacity factor and cost. Renew. Energ., 32: 1453-1466. DOI: 10.1016/j.renene.2006.06.002.

19. Shata, A.S.A. and R. Hanitsch, 2006. The potential of electricity generation on the east coast of Red Sea in Egypt. Renew. Energ., 31: 1597-1615. http:// cat.inist.fr/?aModele=afficheN\&cpsidt=17989845.
20. Hrayshat, E.S., 2007. Wind resource assessment of the Jordanian southern region. Renew. Energ., 32: 1948-1960. http://cat.inist.fr/ ?aModele $=$ afficheN\&cpsidt $=18753482$.

21. Bagiorgas, H.S., M.N. Assimakopoulos, D. Theoharopoulos, D. Matthopoulos and G.K. Mihalakakou, 2007. Electricity generation using wind energy conversion systems in the area of Western Greece. Energ. Convers. Manage., 48: $\quad$ 1640-1655. http://cat.inist.fr/ ?aModele $=$ afficheN\&cpsidt $=18648308$.

22. Yingni, J., Y. Xiuling, F. Jianmei and C. Xiaojun, 2006. Wind power density statistics using the weibull model for inner mongolia, China. Wind Eng., 30: 161-168. http://www.ingentaconnect. $\mathrm{com} /$ content $/ \mathrm{mscp} /$ wind $/ 2006 / 00000030 / 00000002$ /art00007.

23. Ulgen, K., A. Genc and A. Hepbasli et al., 2004. Assessment of wind characteristics for energy generation. Energ. Sources, 26: 1227-1237. http://www.ingentaconnect.com/content/tandf/ueso /2004/00000026/00000013/art00004.

24. Himri, Y., 2005. Optimisation de certains paramètres d'un aérogénérateur situe dans le sud ouest de l'Algérie, Mémoire de magister, Béchar Mai.

25. Haddouche, S., N. Kasbadji, Merzouk and H. Daaou, 2002. Le Centre de Développement Des Energies Renouvelables, Potentiel énergétique éolien, Bulletin des énergies renouvelables, $\mathrm{N}^{\circ} 1$ Juin.

26. SONELGAZ, 2002. Energies Renouvelables OME Task Force on RE Marrakech, Communication.

27. Elimax, H., 2004. Étude stratégique de déploiement de l'énergie éolienne en Afrique, Rapport final, Canada Mars.

28. Retscreen International, 2007. Clean Energy Project Analysis Software, http://www. retscreen.net/ang/centre.ph. 